\title{
Erratum to "A Perspective on Stratigraphic, Vertically-Upward "Displacements or Dislocations" of Conodont-Elements: An Example From the Upper Devonian, Pre-Lithified, Black Shales of the Chattanooga Shale Formation In Tennessee, USA” [Earth Science Research, Vol. 8, No. 2, 2019, pp. 35-51)]
}

\author{
Michael Iannicelli
}

Correspondence: Michael Iannicelli, Brooklyn College (C.U.N.Y.), Brooklyn N.Y.; 710921 Ave. Brooklyn, N.Y. 11204, USA. E-mail: michiann@optonline.net

doi:10.5539/esr.v9n1p14 URL: https://doi.org/10.5539/esr.v9n1p14

doi of original article: $10.5539 /$ esr.v8n2p35

Even though the author already incorporated the citation of Sinninghe-Damste \& Schouten (2006) into the text of the paper, the author regrets having failed to include their full citation within the Reference Section of my above paper which is:

Sinninghe-Damste, J. S. \& Schouton, S. (2006). Biological markers for anoxia in the photic zone of the water column. In, Volkman, J. K. (ed.), Marine Organic Matter: Biomarkers, Isotopes and DNA, (pp. 127 - 163). The Handbook of Environmental Chemistry, vol. 2N. Springer: Berlin and Heidelberg. https://doi.org/10.1007/698_2_005

The author also needs to paraphrase a statement made in the last three lines of the 2nd paragraph on page 40 where it reads as: "Thus, we may conclude here that paleo-upfreezing of any conodont-element(s) originally buried in the pre-lithified, light-colored shale occurred in order to account for their presence in black shale".

Instead, in lieu of that statement, it should read as "At this point in time of the study, we may tentatively conclude here while completely concluding later in the study, that conodont-elements originally existing in the underlying, pre-lithified, light-colored shale, had to paleo-upfreeze vertically upward into pre-lithified, black shale sediment in order to account for their presence in lithified black shale".

\section{Copyrights}

Copyright for this article is retained by the author(s), with first publication rights granted to the journal.

This is an open-access article distributed under the terms and conditions of the Creative Commons Attribution license (http://creativecommons.org/licenses/by/4.0/). 